Volume 1 Issue 2, July-December 2020: pp.119-134.

Faculty of Law, Universitas Lampung, Bandar Lampung, Indonesia.

http://jurnal.fh.unila.ac.id/index.php/ip

P-ISSN: 2723-2638

E-ISSN: $2745-9314$

\title{
Pertanggungjawaban Pidana dalam Pengalihan Objek Jaminan Fidusia Tanpa Persetujuan Penerima Fidusia
}

\section{Criminal Liability in Transferring Fiduciary Security Objects With out the Consent of the Fiduciary}

\author{
Median Dwi Raharjo \\ median_itachi@yahoo.co.id \\ Kepolisian Daerah Lampung
}

Submitted: August 10, 2020; Reviewed: August 31, 2020; Accepted: Sep 212020

Info Artikel
Kata Kunci: Jaminan Fidusia; Tindak
Pidana.
$\begin{aligned} & \text { Keywords: } \quad \text { Fiduciary Guarantee; } \\ & \text { Criminal act. }\end{aligned}$

DOI:

https://doi.org/10.25041/ip.v1i1.2050.
Konsep pelanggaran pidana terkait dengan pemindahan benda fidusia oleh pemberi fidusia tanpa persetujuan fidusia sebagaimana diatur dalam Pasal 36 UU Fidusia adalah masalah dualistik, karena lampiran antara pemberi fidusia dan penerima fidusia didasarkan pada hubungan hukum sipil termuat dalam perjanjian fidusia tetapi di sisi lain dirumuskan sebagai tindak pidana. Masalah dalam penelitian ini adalah bagaimana tanggung jawab pidana fidusia yang mengalihkan objek jaminan fidusia tanpa persetujuan penerima fidusia? dan apa dasar pertimbangan Hakim dalam menjatuhkan putusan terhadap fidusia yang mengalihkan objek jaminan fidusia tanpa persetujuan penerima fidusia? Penelitian ini menggunakan pendekatan penelitian hukum normatif-empiris. Data yang digunakan adalah data primer dan sekunder. Analisis data dilakukan dengan menggunakan analisis kualitatif. Hasil penelitian ini. Tanggung jawab pidana fidusia yang mengalihkan objek jaminan fidusia tanpa persetujuan tertulis dari penerima fidusia sebagaimana dimaksud dalam keputusan kasus Nomor. 43/Pid.B/2018/PN.Kbu didasarkan 
pada kesalahan Terdakwa sebagai pemberi fidusia yang mencakup niat atau kelalaian, sedangkan tindakan yang dilakukan dilarang dan diancam dengan tindak pidana. Lebih jauh, kesalahan yang dilakukan dapat dibuktikan bahwa Tergugat memiliki kemampuan untuk mempertanggungjawabkan tindakannya dan tidak ada alasan untuk memaafkan.

\section{Abstract}

The concept of criminal offense related to the transfer of fiduciary objects by fiduciary givers without the approval of the fiduciary as stipulated in Article 36 of the Fiduciary Law is a dualistic matter, because the attachment between fiduciary givers and fiduciary recipients is based on civil law relations contained in the fiduciary agreement but on the other hand it is formulated as a criminal act. The problem in this study is how is the criminal responsibility of the fiduciary who diverts the object of fiduciary collateral without the consent of the fiduciary recipient? and what is the basis for the Judge's consideration in imposing a judgment on the fiduciary who diverts the object of fiduciary guarantee without the consent of the fiduciary recipient? This study uses a normative-empirical legal research approach. The data used are primary and secondary data. Data analysis is done using qualitative analysis. The results of this study. Fiduciary criminal liability that transfers the object of fiduciary collateral without written approval from the fiduciary recipient as referred to in the Number case decision. 43/Pid.B/2018/PN.Kbu is based on the mistake of the Defendant as the fiduciary giver which includes intentions or negligence, while the acts committed are prohibited and threatened with criminal acts. Furthermore, the mistakes made can be proven that the Defendant has the ability to account for his actions and there is no forgiving reason. 


\section{A. Pendahuluan}

Negara hukum adalah negara yang sistem penyelenggaraan negaranya didasarkan oleh suatu aturan hukum. ${ }^{1}$ Sistem hukum yang berkembang dalam bidang Kekayaan Intelektual di Negara Indonesia sangat dipengaruhi oleh hukum Internasional dan juga oleh hukum NegaraNegara lain. ${ }^{2}$ Keberadaan lembaga jaminan sangat penting bagi kreditur khususnya untuk memberikan kepastian atas terpenuhinya hak yang dimilikinya. Di Indonesia terdapat beberapa lembaga jaminan, salah satunya adalah fidusia, sebagai lembaga jaminan, fidusia memiliki kelebihan dan kekurangan, khususnya dalam pelaksanaan eksekusi, oleh karenanya perlu diketahui bagaimana pelaksanaan eksekusi objek jaminan fidusia khususnya ekesekusi yang didasarkan pada title eksekutotial. ${ }^{3}$ Jaminan fidusia adalah hak jaminan atas benda bergerak baik yang berwujud maupun yang tidak berwujud dan benda tidak bergerak khususnya bangunan sebagaimana dimaksud dalam Undang- Undang Nomor 4 tahun 1996 tentang hak tanggungan yang tetap berada dalam penguasaan pemberi fidusia, sebagai agunan bagi pelunasan uang tertentu yang memberikan kedudukan yang diutamakan kepada penerima fidusia terhadap keditur lainnya. ${ }^{4}$ Berdasarkan Undang-Undang Jaminan Fidusia, diatur pendaftaran jaminan yang memberikan hak yang didahulukan/preferen kepada penerima fidusia terhadap kreditur lain karena jaminan fidusia memberikan hak kepada pihak pemberi fidusia untuk tetap menguasai benda yang menjadi objek jaminan fidusia berdasarkan kepercayaan. ${ }^{5}$

Undang-Undang Nomor 42 Tahun 1999 tentang Jaminan Fidusia (UU Jaminan Fidusia) didasarkan pada realita yang terjadi di masyarakat terkait adanya peningkatan kebutuhan membeli barang dalam bentuk benda bergerak maupun tidak bergerak melalui metode transaksi secara kredit yang selanjutnya pembelian tersebut dituangkan dalam bentuk jaminan fidusia. Fidusia yang berarti penyerahan hak milik atas dasar kepercayaan memberikan kedudukan kepada debitur untuk tetap menguasai barang jaminan, walaupun hanya sebagai peminjam pakai untuk sementara waktu atau tidak lagi sebagai pemilik. ${ }^{6}$ Pengalihan hak kepemilikan adalah pemindahan hak kepemilikan dari pemberi fidusia kepada penerima fidusia atas dasar kepercayaan, dengan syarat bahwa benda yang menjadi objeknya tetap berada di tangan pemberi fidusia. ${ }^{7}$ Timbulnya jaminan fidusia pada dasarnya merupakan sebab dari adanya hubungan keperdataan antara seseorang atau badan hukum yang berkedudukan sebagai debitur dengan perusahaan pembiayaan (finance) yang berkedudukan sebagai kreditur. Jaminan mempunyai fungsi yang sangat penting dalam kegiatan ekonomi pada umumnya karena dalam pemberian pinjaman modal dari lembaga keuangan (baik bank maupun bukan bank) mensyaratkan adanya suatu jaminan, yang harus dipenuhi para pencari modal kalau ia ingin

\footnotetext{
${ }^{1}$ Shandi Patria Airlangga, "Hakikat Penguasa Dalam Negara Hukum Demokratis," Cepalo 3, no. 1 (September 17, 2019): 110, https://doi.org/10.25041/cepalo.v3no1.1783. hlm 2.

${ }^{2}$ Rindia Fanny Kusumaningtyas, "Perkembangan Hukum Jaminan Fidusia Berkaitan dengan Hak Cipta sebagai Objek Jaminan Fidusia." Pandecta: Jurnal Penelitian Ilmu Hukum (Research Law Journal) 11, no. 1 (August 3, 2016): 96-112, https://doi.org/10.15294/pandecta.v11i1.6465. hlm 97.

${ }^{3}$ Heriawanto, "Pelaksanaan Eksekusi Objek Jaminan Fidusia Berdasarkan Title Eksekutorial," Legality: Jurnal Ilmiah Hukum," (accessed July 20, 2020) 54-67, http://ejournal.umm.ac.id/index.php/legality/article/view/8958/6738. hlm 54.

4 “ Kurniawan, "Dampak Pelaksanaan Eksekusi Terhadap Obyek Jaminan Fidusia Berdasarkan Pasal 29 Undang Undang Nomor 42 Tahun 1999 Tentang Jaminan Fidusia." Jurnal Pro Hukum : Jurnal Penelitian Bidang Hukum Universitas Gresik, Vol. VI, No. 1, (Juni 2017): 38-43, http://journal.unigres.ac.id/index.php/JurnalProHukum/article/view/471/347. hlm 39.

${ }^{5}$ Aldo Octavianus, "Hak Debitur Atas Objek Jaminan Fidusia Sebagai Hak Kebendaan Menurut Undang-Undang Nomor 42 Tahun 1999 Tentang Jaminan Fidusia," LEX CRIMEN, vol. 6, No. 10. (January 31, 2018): 99-105, https://ejournal.unsrat.ac.id/index.php/lexcrimen/article/view/18876. hlm 99.

${ }^{6}$ Sri Ahyani, "Perlindungan Hukum Bagi Kreditur Melalui Perjanjian Jaminan Fidusia," Jurnal Wawasan Yuridika, vol. 24, No. 1 (October 28, 2014): 308-319, https://doi.org/10.25072/JWY.V24I1.19. hlm 308.

${ }^{7}$ Setia Budi, "Permohonan Eksekusi Kepada Pengadilan Negeri Berkaitan Dengan Perjanjian Fidusia Terhadap," JCH (Jurnal Cendekia Hukum), vol. 3, No. 1 (September 28, 2017): 99-107, http://www.e-jurnal.stihpm.ac.id/index.php/cendekeahukum/article/view/15. hlm 101.
} 
mendapatkan pinjaman/tambahan modal (berupa kredit) tersebut baik untuk jangka panjang maupun jangka pendek. ${ }^{8}$

Pembebanan fidusia atas objek benda bergerak maupun tidak bergerak yang diperjuabelikan maka kedudukan debitur disebut sebagai pemberi fidusia sedangkan kreditur disebut sebagai penerima fidusia. Fidusia memiliki manfaat bagi debitur dan kreditur, ${ }^{9}$ Benda yang dijadikan objek jaminan fidusia adalah tetap dalam penguasaan pemilik benda (debitur) dan tidak dikuasai oleh kreditur, jadi dalam hal ini adalah penyerahan kepemilikan benda tanpa menyerahkan fisik bendanya. ${ }^{10}$ Pengaturan dan praktik hukum gadai yang mengharuskan objek gadai harus berpindah harus berpindah tangan atau penguasaannya, menyebabkan objek gadai tersebut tidak dapat dimanfaatkan oleh pemiliknya. Dalam jaminan fidusia, kekuatan mengikat kepada objek yang menjadi jaminan fidusia terdapat pada pendaftaran jaminan fidusia itu sendiri, dimana jika jaminan fidusia tersebut tidak didaftarkan, asas publisitas yang merupakan perwujudan dari pendaftaran jaminan fidusia tidak akan ada. ${ }^{11}$ banyak dari objek jaminan Fidusia yang susah untuk dijual kepada masyarakat karena tidak mempunyai nilai jual lagi, misalnya apabila barang tersebut sudah rusak atau cacat secara fisik atau sudah tidak layak lagi digunakan. ${ }^{12}$ Permasalahan yang sering muncul didalam masyarakat terutama pemberi jaminan fidusia terkadang tidak mengetahui adanya aturan larangan pengalihan benda jaminan tanpa persetujuan kreditornya. ${ }^{13}$

Kebutuhan pendanaan masyarakat melalui hukum gadai, yang diatur dalam Bab XX Buku III Kitab Undang-Undang Hukum Perdata untuk kebendaan bergerak, dengan cara melepaskan kebendaan yang dijaminkan tersebut dari penguasaan pihak yang memberikan jaminan kebendaan berupa gadai tersebut. Substansinya, ialah gadai adalah hak kebendaan bergerak, dan gadai berpindah penguasaannya. ${ }^{14}$ Penegakna hukum juga diperlukan karena terletak pada kegiatan menyerasikan hubungan nilai-nilai yang terjabarkan di dalam kaidahkaidah yang mantap dan mengejawantah dan sikap tindak sebagaimana rangkaian penjabaran nilai tahap akhir, untuk menciptakan, memelihara, dan mempertahankan kedamaian pergaulan hidup. ${ }^{15}$ Terciptanya interaksi sosial terkait jual beli terhadap benda yang dibebankan dengan jaminan fidusia seringkali menimbulkan sebuah problematika hukum yang berdampak pada terjadinya suatu konflik yang pada akhirnya akan melahirkan suatu kejahatan atau tindak pidana, sehingga tidak dapat dipungkiri bahwa tindak pidana telah menjadi bagian yang tidak terpisahkan dalam pelaksanaan jaminan fidusia. Secara yuridis, perbuatan yang dilakukan dalam ruang lingkup pelaksanaan jaminan fidusia dapat dikategorikan sebagai perbuatan pidana apabila melanggar

\footnotetext{
8 Jatmiko Winarno, "Perlindungan Hukum Bagi Kreditur Pada Perjanjian Jaminan Fidusia,” Jurnal Independent 1, no. 1 (June 1, 2013): 44-55, http://jurnalhukum.unisla.ac.id/index.php/independent/article/view/5. hlm 44.

9 Oleh: Hengky, and Setiawan Kaendo, "Perampasan Oleh Penagih Hutang Terhadap Kendaraan Sebagai Objek Jaminan Fidusia," LEX ET SOCIETATIS, vol. 7, No. $4 \quad$ (July $30, \quad 2019$ ): $26-33$ https://ejournal.unsrat.ac.id/index.php/lexetsocietatis/article/view/24700.

${ }^{10}$ Munir Fuady, Fidusia, Bandung: Citra Aditya Bakti, 2003, hlm. 152.

11 Richard Leonard Jinata, "Tinjauan Yuridis Mengenai Peran Dan Tanggung Jawab Notaris Dalam Pembebanan Jaminan Fidusia," LEX PRIVATUM, vol. VI, No. 8 (February 4, 2018): 120-130, https://ejournal.unsrat.ac.id/index.php/lexprivatum/article/view/22867. hlm 122.

${ }^{12}$ David Novan Setyawan, "Upaya Perlindungan Kepada Pihak Bank Akibat Adanya Pengalihan Objek Jaminan Fidusia Yang Dialihkan Oleh Pihak Nasabah Tanpa Adanya Persetujuan Terlebih Dahulu Dari Pihak Bank (Studi Kasus Di PT. Bank Negara Indonesia, Malang)Adapun Upaya Untuk Memberikan," DIVERSI: Jurnal Hukum 2, no. 1 (May 4, 2018): 353-362, https://doi.org/10.32503/diversi.v2i1.144. hlm 360.

${ }^{13}$ M Sriono and Kn, "Tanggung Jawab Pemberi Fidusia Terhadap Benda Jaminan Fidusia Dalam Perjanjian Kredit," Jurnal Ilmiah "Advokasi 07, no. 02 (September 15, 2019): 149-59, https://doi.org/10.30641/dejure.2018.V18.183. hlm 153.

14 Mick Mario Valentino Sopacoly, "Akibat Hukum Terhadap Pembebanan Jaminan Fidusia Yang Tidak Didaftarkan," Lex Administratum, Vol. V, No. 4 (Jun 2017): 5-16 https://ejournal.unsrat.ac.id/index.php/administratum/article/view/16126. hlm 8.

${ }^{15}$ Ridwan, "Efektivitas Penegakan Hukum Tindak Pidana Fidusia Dalam Proses Penyidikan (Studi Di Polres Banyumas)." Jurnal Idea Hukum,"(accessed July 20, 2020): 1521-1531, http://jih.fh.unsoed.ac.id/index.php/jih/article/view/1521-1531/104. hlm. 1523.
} 
ketentuan Pasal 36 UU Jaminan Fidusia yang menentukan bahwa pemberi fidusia yang mengalihkan, menggadaikan, atau menyewakan benda yang menjadi objek jaminan fidusia sebagaimana dimaksud dalam Pasal 23 Ayat (2) yang dilakukan tanpa persetujuan tertulis terlebih dahulu dari penerima fidusia, dipidana dengan pidana penjara paling lama 2 (dua) tahun dan denda paling banyak Rp. 50.000.000,- (lima puluh juta rupiah). Perbuatan tersebut tentu sangat merugikan perusahaan dan juga merupakan persoalan tindak pidana penggelapan yang harus disikapi bersama oleh pihak yang berkepentingan. ${ }^{16}$

Diaturnya ketentuan pidana dalam UU Jaminan Fidusia telah membawa konsekuensi yuridis bagi setiap orang yang melanggar ketentuan tersebut untuk dimintakan pertanggungjawaban pidana. Adapun contoh kasus tindak pidana pengalihan objek jaminan fidusia tanpa persetujuan pemberi fidusia yang telah diputus oleh pengadilan adalah perkara Nomor 43/Pid.B/2018/PN Kbu atas nama Terdakwa Meri Noprianti Binti Mursidin, melalui putusannya Hakim menjatuhkan pidana penjara selama 1 (satu) bulan dan denda sebesar Rp. 50.000.000 (lima puluh juta rupiah) dengan ketentuan apabila denda tidak dibayar akan diganti dengan pidana penjara selama 1 (satu) bulan atas terbuktinya perbuatan Terdakwa melanggar ketentuan Pasal 36 UU Fidusia. Konsepsi tindak pidana sebagaimana diatur dalam Pasal 36 UU Fidusia menurut penulis merupakan suatu hal yang bersifat dualistis, sebab apabila mencermati ketentuan Pasal 4 UU Jaminan Fidusia disebutkan bahwa jaminan fidusia merupakan perjanjian ikutan dan suatu perjanjian pokok yang menimbulkan kewajiban bagi para pihak untuk memenuhi suatu prestasi. Berdasarkan ketentuan tersebut dapat dipahami bahwa segala sesuatu yang berkaitan dengan pelaksanaan perjanjian jaminan fidusia apabila menimbulkan kerugian bagi para pihak cukup beralasan hukum untuk dimintakan pertanggungjawaban hukum melalui sarana gugatan perdata, sebab esensi dari jaminan fidusia adalah didasarkan pada suatu perjanjian.

Akan tetapi apabila mencermati ketentuan Pasal 36 UU Fidusia maka diketahui bahwa UU Fidusia justru membuka peluang adanya pertanggungjawaban secara pidana apabila dalam pelaksanan perjanjian fidusia pemberi fidusia mengalihkan, menggadaikan atau menyewakan benda yang menjadi objek jaminan fidusia tanpa adanya persetujuan dari penerima fidusia. Beranjak dari adanya penafsiran hukum yang bersifat dualistis terkait dengan jaminan fidusia dimaksud maka melalui tulisan ini diharapkan dapat memperjelas mengenai konsepsi pertanggungjawaban pidana pemberi fidusia dalam mengalihkan objek jaminan fidusia tanpa persetujuan penerima fidusia. Penelitian ini menggunakan pendekatan penelitian hukum normatif-empiris data yang digunakan adalah data primer dan sekunder Analisis data dilakukan dengan menggunakan cara analisis kualitatif.

\section{B. Pembahasan}

\section{Pertanggungjawaban Pidana Pemberi Fidusia yang Mengalihkan Objek Jaminan Fidusia Tanpa Persetujuan Penerima Fidusia}

Fidusia berasal dari kata "fides" yang berarti kepercayaan. Sesuai dengan arti kata ini maka hubungan hukum antara debitor dan kreditor merupakan hubungan hukum yang didasarkan kepercayaan. ${ }^{17}$ Subjek jaminan fidusia adalah pemberi fidusia dan penerima fidusia. Dalam UU Jaminan Fidusia yang dimaksud dengan pemberi fidusia adalah orang perseorangan atau korporasi pemilik benda yang menjadi objek jaminan fidusia. Sedangkan yang dimaksud dengan penerima fidusia adalah orang perseorangan atau korporasi yang mempunyai piutang yang pembayarannya dijamin dengan jaminan fidusia. Adapun yang menjadi objek fidusia

\footnotetext{
${ }^{16}$ R.Suharto, Faizal Pratama Febriansyah* Purwoto, "Tinjauan Yuridis Kasus Pengalihan Barang Jaminan Fidusia Dari Sudut Hukum Pidana (Studi Kasus Pengadilan Negeri Jepara No.320/Pid.Sus/ 2011/Pn.Jpr Jo No.101/Pid/2012/ Pt.Smg Jo N," Diponegoro Law Review, vol. 5. No. 2, (2016): 1-16, https://ejournal3.undip.ac.id/index.php/dlr/. hlm 4.

${ }^{17}$ Gunawan Wijaya dan Ahmad Yani, Jaminan Fidusia, Jakarta: Raja Graindo Persada, 2001, hlm. 113.
} 
dalam UU Jaminan Fidusia dibagi menjadi 2 (dua) bentuk, yaitu benda yang dapat dimiliki dan dialihkan, baik yang berwujud maupun yang tidak berwujud, yang terdaftar maupun yang tidak terdaftar, yang bergerak maupun yang tak bergerak yang tidak dapat dibebani hak tanggungan atau hipotek. Secara yuridis, jaminan fidusia timbul dari adanya perjanjian yang selanjutnya akan diikuti dengan adanya pengalihan kepemilikan benda dari debitor selaku pemberi fidusia kepada kreditor selaku penerima fidusia sebagai jaminan atas hutang dengan kesepakatan bahwa kreditor akan mengalihkan kembali kepemilikan benda tersebut apabila hutang telah dilunasi oleh kreditor.

Menurut Faisal Zhuhry dalam wawancara yang dilakukan penulis menerangkan bahwa perbuatan mengalihkan objek jaminan fidusia tanpa persetujuan tertulis dari penerima fidusia secara absolut merupakan perbuatan pidana, sebab prisip pengalihan jaminan fidusia berdasarkan ketentuan Pasal 19 UU Jaminan Fidusia adalah sebagai berikut:

a. Pengalihan hak atas piutang yang dijamin dengan fidusia mengakibatkan beralihnya demi hukum segala hak dan kewajiban penerima fidusia kepada kreditor baru.

b. Beralihnya jaminan fidusia sebagaimana dimaksud dalam Ayat (1) didaftarkan oleh kreditor baru kepada kantor pendaftaran fidusia.

Ketentuan tersebut menegaskan bahwa setiap peralihan jaminan fidusia yang dilakukan akan menimbulkan akibat hukum baru, dengan demikian apabila pengalihan objek jaminan fidusia dilakukan tanpa adanya persetujuan dari penerima fidusia baik dengan menggunakan akta otentik maupun akta di bawah tangan dapat dikategorikan sebagai perbuatan pidana, sebab perbuatan tersebut tidak sesuai dengan prosedur yang diatur dalam UU Jaminan Fidusia. Adapun yang dimaksud dengan mengalihkan sebagaimana diatur dalam Penjelasan Pasal 21 UU Jaminan Fidusia antara lain termasuk menjual atau menyewakan dalam rangka kegiatan usahanya. ${ }^{18}$ Adapun konsepsi perbuatan pidana terkait dengan pengalihan objek jaminan fidusia diatur dalam Pasal 36 UU Jaminan Fidusia yang menentukan bahwa pemberi fidusia yang mengalihkan, menggadaikan, atau menyewakan benda yang menjadi objek jaminan fidusia sebagaimana dimaksud dalam Pasal 23 Ayat (2) yang dilakukan tanpa persetujuan tertulis terlebih dahulu dari penerima fidusia, dipidana dengan pidana penjara paling lama 2 (dua) tahun dan denda paling banyak Rp. 50.000.000,- (lima puluh juta) rupiah.

Pemidanaan merupakan perwujudan pidana dalam bentuk konkrit, dengan demikian diketahui bahwa sebelum pemidanaan dijatuhkan oleh Hakim maka harus terdapat perbuatan pidana yang dilakukan oleh seseorang. Untuk dapat menjatuhkan pidana kepada seseorang disyaratkan adanya tindak pidana yang dilakukan serta memenuhi unsur-unsur dalam ketentuan undang-undang yang dilanggar. Seseorang akan dimintakan pertanggungjawaban pidana atas perbuatan yang dilakukan apabila perbuatan tersebut memenuhi unsur kesalahan dan bersifat melawan hukum serta tidak ada alasan pembenaran atas perbuatan yang dilakukannya.

Pembicaraan mengenai pertanggungjawaban pidana tidak dapat dilepaskan dari pembicaraan mengenai perbuatan pidana yang sangat erat kaitanya dengan kesalahan yang dilakukan. Seseorang yang melakukan tindak pidana baru dapat dihukum apabila pelaku dinyatakan sanggup untuk mempertanggungjawabkan perbuatan yang telah dilakukannya. KUHP tidak memberikan definisi secara jelas mengenai yang dimaksud dengan pertanggungjawaban pidana. KUHP hanya memberikan pengecualian terhadap seseorang yang tidak dapat dituntut pertanggungjawaban pidana apabila orang tersebut melakukan perbuatan pidana sebagaimana diatur dalam Pasal 44 KUHP yang menentukan bahwa barang siapa melakukan perbuatan yang tidak dapat dipertanggungjawabkan kepadanya, karena jiwanya cacat dalam tumbuhnya atau jiwa yang terganggu karena penyakit tidak dipidana.

${ }^{18}$ Wawancara dengan Faisal Zhuhry selaku Hakim pada Pengadilan Negeri Kotabumi pada tanggal 21 Maret 2019 pukul 10.30 WIB. 
Penerapan pertanggungjawaban pidana hanya dapat dibebankan kepada subjek tindak pidana itu sendiri, dalam hal ini adalah seseorang yang melakukan tindak pidana. Ketentuan mengenai orang sebagai subjek yang dapat dimintakan pertanggungjawaban pidana diatur dalam Pasal 55 KUHP yaitu:

1) Dipidana sebagai pelaku tindak pidana adalah mereka yang melakukan, yang menyuruh melakukan, dan yang turut serta melakukan perbuatan. Dan mereka yang dengan memberi atau menjanjikan sesuatu dengan menyalahgunakan kekuasaan atau martabat, dengan kekerasan, ancaman atau penyesatan, atau dengan memberi kesempatan, sarana atau keterangan, sengaja menganjurkan orang lain supaya melakukan perbuatan.

2) Terhadap penganjur, hanya perbuatan yang sengaja dianjurkan sajalah yang diperhitungkan, beserta akibat-akibatnya.

Moeljatno menyatakan bahwa pertanggungjawaban pidana atau kesalahan menurut hukum pidana terdiri atas tiga syarat yakni kemampuan bertanggung jawab atau dapat dipertanggungjawabkan dari pembuat, adanya perbuatan melawan hukum yaitu suatu sikap psikis pelaku yang berhubungan dengan kelakuannya, yaitu disengaja dan sikap kurang hatihati atau lalai. Serta tidak ada alasan pembenar atau alasan yang menghapuskan pertanggungjawaban pidana bagi si pembuat. ${ }^{19}$

Berdasarkan teori tersebut, dapat dipahami bahwa syarat utama pertanggungjawaban pidana adalah terbuktinya kesalahan terdakwa dalam melanggar ketentuan undang-undang, selanjutnya atas kesalahan tersebut diketahui bahwa Terdakwa adalah orang yang memiliki kemampuan untuk bertanggungjawab secara pidana, dalam hal ini kedudukan terdakwa bukanlah pada posisi sebagai orang yang tidak dapat dijatuhi pidana berdasarkan ketentuan Pasal 44 Ayat (1) KUHP, Pasal 48 KUHP, Pasal 49 KUHP, Pasal 50 KUHP dan Pasal 51 KUHP. Gunawan Jatmiko menerangkan bahwa pertanggungjawaban pidana terjadi karena adanya kesalahan dari pelaku pengalihan objek jaminan fidusia yang meliputi kesengajaan dan kelalaian. Unsur kesengajaan merupakan salah satu unsur yang terpenting didalam rumusan Pasal 36 UU Jaminan Fidusia yang dikonsepsikan sebagai perbuatan pidana, maka unsur kesengajaan ini meliputi juga unsur lain berupa perbuatan yang tercantum di dalamnya dan harus dibuktikan. Sengaja berarti adanya kehendak yang disadari dan ditujukan untuk melakukan perbuatan pengalihan objek jaminan fidusia, maka berkaitan dengan pembuktian bahwa perbuatan tersebut dilakukan dengan sengaja terkandung pengertian menghendaki dan mengetahui.

Selain itu, terdapat unsur kelalaian atau kealpaan. Faktor terpenting dalam unsur ini adalah pelaku dapat menduga terjadinya akibat dari perbuatannya itu atau pelaku kurang berhati-hati, pelaku mempunyai kesadaran atau pengetahuan adanya akibat yang ditimbulkan dari perbuatan tersebut, dengan kata lain pelaku mengetahui bahwa jika melakukan pengalihan objek jaminan fidusia tanpa persetujuan penerima fidusia dapat dikenakan hukuman pidana. ${ }^{20}$ Pertanggungjawaban pidana atas dilanggarnya ketentuan Pasal 36 UU Jaminan Fidusia dalam perkara Nomor 43/Pid.B/2018/PN.Kbu, dapat dianalisis dengan mendasar pada unsur-unsur pertanggungjawaban pidana sebagaimana dikemukakan oleh E.Y. Kanter dan S.R. Sianturi yang meliputi:

a. Subjek harus sesuai dengan perumusan undang-undang;

b. Terdapat kesalahan pada petindak;

c. Tindakan itu bersifat melawan hukum;

d. Tindakan itu dilarang dan diancam dengan pidana oleh undang-undang (dalam arti luas);

\footnotetext{
${ }^{19}$ Moeljatno, Perbuatan Pidana dan Pertanggungjawaban dalam Hukum Pidana, Jakarta: Bina Aksara, 1983, hlm 153.

${ }^{20}$ Wawancara dengan Gunawan Jatmiko selaku Dosen Fakultas Hukum Universitas Lampung pada tanggal 25 Maret 2019 pukul 15.00 WIB.
} 
e. Dilakukannya tindakan itu sesuai dengan tempat, waktu dan keadaan lainnya yang ditentukan dalam undang-undang. ${ }^{21}$

Berdasarkan hal tersebut, maka pertanggungjawaban pidana pemberi fidusia yang mengalihkan objek jaminan fidusia tanpa persetujuan penerima fidusia menurut analisis penulis adalah sebagai berikut:

Bahwa Subjek harus sesuai dengan perumusan undang-undang, maksudnya adalah yang dimintakan pertanggungjawaban pidana dalam perkara Nomor 43/Pid.B/2018/PN.Kbu adalah seorang terdakwa yang bernama Meri Nopriyanti, S.Pd. Binti Mursidin, dalam hal ini berkedudukan sebagai konsumen sekaligus sebagai pemberi jaminan fidusia terhadap PT Indomobil Finance sebagai lembaga pembiayaan sekaligus sebagai penerima jaminan fidusia atas objek jaminan fidusia berupa 1 (satu) unit mobil Suzuki Karimun Wagon sebagaimana tertuang dalam:

1) Perjanjian Pembiayaan Konsumen dan Pengakuan Hutang tanggal 02 September 2016.

2) Surat Kuasa membebankan jaminan Fidusia tanggal 02 September 2017.

3) Akta Fidusia nomor 5 tanggal 08 September 2016.

4) Sertifikat Fidusia Nomor W9.00118603.05.01 Tahun 20162016 tanggal 14 September 2016.

Kemudian terdapat kesalahan pada petindak yang berkaitan dengan pelaksanaan perjanjian fidusia antara terdakwa selaku pemberi fidusia dan PT Indomobil Finance selaku penerima fidusia, Terdakwa telah melakukan pengalihan objek jaminan fidusia berupa 1 (satu) unit mobil Suzuki Karimun Wagon kepada orang lain tanpa persetujuan tertulis dari penerima fidusia. Perbuatan tersebut dapat dinilai sebagai bentuk kesalahan yang dilakukan oleh Terdakwa selaku pemberi jaminan fidusia, sebab berdasarkan Pasal 23 Ayat (2) UU Jaminan Fidusia secara jelas ditentukan bahwa pemberi fidusia dilarang mengalihkan, menggadaikan, atau menyewakan kepada pihak lain benda yang menjadi objek jaminan fidusia yang tidak merupakan benda persediaan, kecuali dengan persetujuan tertulis terlebih dahulu dari penerima fidusia.

Bahwa tindakan itu bersifat melawan hukum, menurut Schaffmeister sebagaimana dikutip oleh J.E Sahetapy, menyatakan bahwa terdapat empat makna yang terkandung dalam sifat perbuatan melawan hukum, yaitu:

a. Sifat melawan hukum umum (suatu perbuatan yang dilarang dalam ketentuan hukum pidana memiliki sifat melawan hukum walaupun tidak tertulis secara eksplisit).

b. Sifat melawan hukum khusus (suatu perbuatan memiliki sifat melawan hukum khusus pada saat rumusan ketentuan hukum pidananya memuat istilah "melawan hukum").

c. Sifat melawan hukum formal (perbuatan memenuhi tiap rumusan ketentuan hukum pidana yang berlaku).

d. Sifat melawan hukum materiil (suatu perbuatan memiliki sifat melawan hukum materiil karena perbuatan tersebut melanggar atau membahayakan kepentingan hukum yang hendak dilindungi oleh pembentuk undang-undang). ${ }^{22}$ Berdasarkan sifat-sifat melawan hukum tersebut, diketahui bahwa setiap subjek hukum yang berkedudukan sebagai pemberi fidusia yang melakukan perbuatan pengalihan objek jaminan fidusia tanpa persetujuan penerima fidusia maka perbuatan tersebut dapat dinilai sebagai perbuatan yang bersifat melawan hukum dengan melanggar ketentuan yuridis dalam Pasal 23 Ayat (2) UU Jaminan Fidusia dan Pasal 36 UU Jaminan Fidusia.

e. Tindakan itu dilarang dan diancam dengan pidana oleh undang-undang.

\footnotetext{
${ }^{21}$ E E.Y Kanter \& S.R. Sianturi, Asas-Asas Hukum Pidana di Indonesia dan Penerapannya, Jakarta: Storia Grafika, 2002, hlm 253.

${ }^{22}$ J.E. Sahetapy \& Agustinus Pohan, Hukum Pidana, Bandung: Citra Aditya Bakti, 2007, hlm 37.
} 
Tindakan yang dilakukan oleh Terdakwa selaku pemberi jaminan fidusia berupa mengalihkan objek jaminan fidusia merupakan suatu perbutan yang secara yuridis telah dikonsepsikan sebagai perbuatan yang dilarang dan diancam dengan pidana dalam Pasal 23 Ayat (2) UU Jaminan Fidusia dan Pasal 36 UU Jaminan Fidusia. Dilakukannya tindakan itu sesuai dengan tempat, waktu dan keadaan lainnya yang ditentukan dalam undang-undang. Tempat dilakukannya perbuatan pengalihan objek jaminan fidusia dinilai sangat penting dalam kaitanya dengan pertanggungjawaban pidana, sebab hal tersebut berhubungan dengan ketentuan Pasal 2 KUHP yang menyebutkan bahwa ketentuan pidana dalam perundangundangan dangan Indonesia diterapkan bagi setiap orang yang melakukan sesuatu tindak pidana di Indonesia, disamping itu hal tersebut juga berkaitan dengan kompetensi relatif pengadilan mana yang berwenangan mengadili tindak pidana tersebut. Selanjutnya mengenai waktu dilakukannya perbuatan pengalihan objek jaminan fidusia juga bernilai penting sebab hal tersebut berkaitan dengan asas legalitas sebagaimana diatur dalam Pasal 1 Ayat (1) KUHP yang menentukan bahwa suatu perbuatan tidak dapat dipidana, kecuali berdasarkan kekuatan ketentuan perundang-undangan pidana yang telah ada. Adapun terhadap keadaan lain yang ditentuakan dalam undang-undang adalah keadaan-keadaan yang berkaitan dengan pemidanaan sebagaimana diatur dalam Pasal 44 KUHP, 48 KUHP, 49 KUHP, 50 KUHP dan 51 KUHP.

Selain mengacu pada teori sebagaimana dikemukakan oleh E.Y. Kanter dan S.R. Sianturi tersebut, konsepsi pertanggungjawaban pidana pengalihan objek jaminan fidusia juga tidak dapat dipisahkan oleh teori yang dikemukakan oleh Van Hamel yang menyatakan bahwa kemampuan bertanggungjawab adalah suatu keadaan normalitas psychis dan kematangan (kecerdasan) yang membawa tiga kemampuan yakni, mampu untuk mengerti nilai dari akibatakibat perbuatannya sendiri, mampu untuk menyadari bahwa perbuatannya itu menurut pandangan masyarakat tidak dibolehkan, dan mampu untuk menentukan kehendak perbuatannya. $^{23}$

Berdasarkan teori tersebut maka diketahui bahwa normalitas psychis dan kematangan seorang terdakwa juga menjadi tolok ukur kemampuan pertanggungjawaban pidana atas perbuatan yang dilakukan serta dapat mempengaruhi bentuk putusan yang akan dijatuhkan oleh Hakim, hal tersebut terdapat relevansinya dengan Pasal 44 KUHP yang menentukan:

1) Barang siapa melakukan perbuatan yang tidak dapat dipertanggungjawabkan kepadanya karena jiwanya cacat dalam pertumbuhan atau terganggu karena penyakit, tidak dipidana.

2) Jika ternyata perbuatan itu tidak dapat dipertanggungkan kepada pelakunya karena pertumbuhan jiwanya cacat atau terganggu karena penyakit, maka hakim dapat memerintahkan supaya orang itu dimasukkan ke rumah sakit jiwa, paling lama satu tahun sebagai waktu percobaan.

3) Ketentuan dalam Ayat 2 hanya berlaku bagi Mahkamah Agung, Pengadilan Tinggi, dan Pengadilan Negeri.

\section{Dasar Pertimbangan Hakim dalam Menjatuhkan Putusan Pemidanaan Terhadap Pemberi Fidusia yang Mengalihkan Objek Jaminan Fidusia Tanpa Persetujuan Penerima Fidusia}

Menurut E. A. Goebel, sebagaimana dikutip oleh Ronny Hanitijosoemitro, menyatakan bahwa terdapat empat fungsi dasar hukum dalam masyarakat, yaitu:

a. Menetapkan pola hubungan antara anggota-anggota masyarakat dengan cara menunjukkan jenis-jenis tingkah laku yang diperbolehkan dan yang dilarang;

b. Menentukan alokasi wewenang, merinci siapa yang boleh melakukan paksaan, siapa yang memilih sanksi yang tepat dan efektif;

\footnotetext{
${ }^{23}$ Nikmah Rosidah, Asas-Asas Hukum Pidana, Semarang: Pustaka Magister Semarang, 2011, hlm 38.
} 
c. Menyelesaikan sengketa;

d. Memelihara kemampuan masyarakat untuk mampu menyesuaikan diri dengan kondisikondisi kehidupan yang berubah, yaitu dengan cara merumuskan kembali hubunganhubungan esensial antara anggota-anggota masyarakat. ${ }^{24}$

Tujuan utama dilakukannya proses persidangan di pengadilan adalah untuk memperoleh putusan Hakim. Putusan Hakim pada prinsipnya merupakan suatu keputusan yang diucapkan di sidang pengadilan dengan tujuan untuk menyelesaikan perkara yang sedang ditanganinya. Putusan Hakim akan dinilai memiliki kewibawaan jika putusan tersebut dapat merefleksikan rasa keadilan bagi setiap pihak-pihak yang terlibat di persidangan maupun bagi masyarakat secara menyeluruh. Sebelum menjatuhkan putusan, Hakim terlebih dahulu harus menelaah tentang kebenaran peristiwa yang diajukan kepadanya kemudian memberi penilaian terhadap peristiwa tersebut dan menghubungkannya dengan hukum yang berlaku, setelah itu Hakim baru dapat menjatuhkan putusan terhadap peristiwa tersebut.

Proses pembuatan putusan oleh Hakim di pengadilan terutama dalam perkara pidana, merupakan suatu proses kompleks dan sulit dilakukan sehingga memerlukan pelatihan, pengalaman, dan kebijaksanaan. Sebagai figur sentral, para Hakim memiliki kewajiban moral dan tanggung jawab profesional. Dengan adanya kecukupan pengetahuan dan keterampilan teknis, para Hakim dalam memutus suatu perkara dapat memberikan pertimbangan hukum (legal reasoning) yang tepat dan benar. ${ }^{25}$ Menurut Faisal Zhuhry dalam wawancara yang dilakukan penulis, mengemukakan bahwa secara yuridis terdapat beberapa syarat yang harus dipenuhi apabila hakim akan menjatuhkan putusan pemidanaan terhadap Terdakwa, antara lain adalah sebagai berikut: ${ }^{26}$

a. Proses pembuktian yang sah menurut undang-undang.

b. Terbuktinya pebuatan yang didakwakan Penuntut Umum kepada Terdakwa berdasarkan sekurang-kurangnya 2 (dua) alat bukti yang sah.

c. Adanya keyakinan hakim.

d. Adanya kesalahan Terdakwa dalam melakukan tindak pidana yang didakwakan kepadanya.

e. Terdakwa memiliki kemampuan bertanggungjawab.

Penjelasan selanjutnya yang dikemukakan oleh Faisal Zhuhry dalam wawancara yang dilakukan penulis, menerangkan bahwa dalam memutus perkara pidana dasar pertimbangan yang seringkali digunakan oleh Hakim yang meliputi yang pertama pertimbangan yuridis yaitu unsur primer dalam setiap putusan Hakim, sebab Hakim dalam menjatuhkan putusan harus didasarkan pada surat dakwaan yang selanjutnya mencari kebenaraan materiil melalui proses pembuktian dengan berpedoman pada ketentuan KUHAP seta undang-undang lain yang terdapat relevansinya dengan perkara yang sedang diperiksa. Kedua pertimbangan non yuridis merupakan pertimbangan hukum yang bersumber dari segala sesuatu yang berada diluar ketentuan yuridis, berkaitan dengan tujuan penjatuhan putusan, bentuk sanksi pidana yang akan dijatuhkan terhadap Terdakwa dengan mendasar pada kesalahan Terdakwa, motivasi Terdakwa melakukan perbuatan pidana dan akibat yang ditimbulkan atas perbuatan Terdakwa. Dan penilaian atas hal-hal yang meringankan maupun yang memberatkan Terdakwa. Serta, keadaan

\footnotetext{
${ }^{24}$ Ronny Hanitijosoemitro, Op.Cit., hlm. 2.

${ }^{25}$ M. Syamsuddin, Konstruksi Baru Budaya Hukum Hakim Berbasis Hukum Progresif, Jakarta: Kencana, 2012, hlm 85.

${ }^{26}$ Wawancara dengan Faisal Zhuhry selaku Hakim pada Pengadilan Negeri Kotabumi pada tanggal 21 Maret 2019 pukul 10.30 WIB.
} 
psikis Terdakwa pada saat melakukan perbuatan pidana, hingga sebab-sebab Terdakwa melakukan perbuatan pidana. ${ }^{27}$

Berkaitan dengan dasar pertimbangan Hakim dalam menjatuhkan putusan pemidanaan, guna menganalisis hal tersebut maka penulis mengacu pada teori sebagaimana dikemukakan oleh Sudarto yang membagi dasar pertimbangan Hakim dalam menjatuhkan putusan meliputi 3 (tiga) aspek, yaitu: Pertimbangan yuridis, maksudnya adalah hakim mendasarkan putusannya pada ketentuan peraturan perundang-undangan secara formil. Hakim secara yuridis, tidak boleh menjatuhkan pidana tersebut kecuali apabila dengan sekurang- kurangnya dua alat bukti yang sah, sehingga hakim memperoleh keyakinan bahwa suatu tindak pidana benar-benar terjadi dan terdakwalah yang bersalah melakukannya (Pasal 183 KUHAP). Alat bukti sah yang dimaksud adalah: (a). Keterangan Saksi; (b). Keterangan Ahli; (c). Surat; (d). Petunjuk; (e). Keterangan Terdakwa atau hal yang secara umum sudah diketahui sehingga tidak perlu dibuktikan (Pasal 184). Selain itu dipertimbangkan pula bahwa perbuatan terdakwa melawan hukum formil dan memenuhi unsur-unsur tindak pidana yang dilakukan. Pertimbangan filosofis, maksudnya hakim mempertimbangkan bahwa pidana yang dijatuhkan kepada terdakwa merupakan upaya untuk memperbaiki perilaku terdakwa melalui proses pemidanaan. Hal ini bermakna bahwa filosofi pemidanaan adalah pembinaan terhadap pelaku kejahatan sehingga setelah terpidana keluar dari lembaga pemasyarakatan, akan dapat memperbaiki dirinya dan tidak melakukan kejahatan lagi. Pertimbangan sosiologis, maksudnya hakim dalam menjatuhkan pidana didasarkan pada latar belakang sosial terdakwa dan memperhatikan bahwa pidana yang dijatuhkan mempunyai manfaat bagi masyarakat. ${ }^{28}$

Berdasarkan penelitian yang dilakukan penulis, diketahui bahwa Hakim dalam pemeriksaan suatu perkara memerlukan adanya pembuktian, dimana hasil dari pembuktian itu digunakan sebagai bahan pertimbangan dalam memutus perkara, pembuktian merupakan tahap yang paling penting dalam pemeriksaan di persidangan. Pembuktian bertujuan untuk memperoleh kepastian bahwa suatu peristiwa atau fakta yang diajukan itu benar-benar terjadi, sehingga Hakim tidak keliru dalam menjatuhkan putusan. Adapun yang menjadi dasar pertimbangan Hakim dalam menjatuhkan putusan pemidanaan terhadap pemberi fidusia yang mengalihkan objek jaminan fidusia tanpa persetujuan tertulis dari penerima fidusia dalam perkara Nomor 43/Pid.B/2018/PN.Kbu meliputi hal-hal yang bersifat yuridis, diantaranya: Dakwaan Penuntut Umum yang berdasarkan fakta persidangan, Hakim berkesimpulan dan berkeyakinan bahwa Terdakwa Meri Nopriyanti Binti Mursidin telah terbukti melakukan tindak pidana pengalihan objek jaminan fidusia tanpa persetujuan penerima fidusia sebagaimana termuat dalam dakwaan kedua Penuntut Umum yaitu melanggar Pasal 36 Jo. Pasal 23 Ayat (2) Undang-Undang Nomor 42 Tahun 1999 tentang Jaminan Fidusia. Kemudian keterangan saksi dan Terdakwa, maksdunya adalah setelah mendengar keterangan saksi dan Terdakwa diperoleh fakta persidangan bahwa benar Terdakwa selaku pemberi jaminan fidusia telah mengalihkan objek jaminan fidusia berupa 1 (satu) unit mobil Suzuki Karimun Wagon R.1.0 AB GL MT warna merah metalik tanpa persetujuan tertulis dari PT Indomobil Finance salaku penerima fidusia. Serta barang bukti yang diajukan dalam persidangan.Selama pemeriksaan persidangan Penuntut Umum mengajukan barang bukti berupa:

a) Akta Fidusia Nomor 5 tanggal 08 September 2016.

b) Sertifikat Fidusia Nomor W9.00118603.05.01 tanggal 14 September 2016.

c) Surat Pembiayaan Konsumen dan Pengakuan Hutang (PPKDPH) tanggal 02 September 2016.

d) Surat Kuasa Membebankan Jaminan Fidusia tanggal 02 September 2017.

\footnotetext{
${ }^{27}$ Wawancara dengan Faisal Zhuhry selaku Hakim pada Pengadilan Negeri Kotabumi pada tanggal 21 Maret 2019 pukul 10.30 WIB.

${ }^{28}$ Sudarto, Kapita Selekta Hukum Pidana, Alumni, Bandung, 1986, hlm, 67.
} 
e) Surat Kuasa Penarikan kendaraan/Alat Berat tanggal 02 September 2017.

Hal-hal yang bersifat filosofis, yakni pertimbangan filosofis penjatuhan putusan pemidanaan didasarkan pada tujuan untuk melaksanakan penegakan hukum berkaitan dengan undang-undang yang telah dilanggar oleh Terdakwa. Hal-hal yang bersifat sosiologis, meliputi latar belakang perbuatan Terdakwa. Latar belakang Terdakwa Meri Nopriyanti Binti Mursidin melakukan tindak pidana disebabkan karena adanya kesempatan dan sarana untuk mengalihkan objek jaminan fidusia, hal tersebut dilatarbelakangi oleh adanya niat untuk memperoleh keuntungan ekonomi secara melawan hukum, akibat perbuatan Terdakwa. Perbuatan terdakwa Meri Nopriyanti Binti Mursidin dalam mengalihkan objek jaminan fidusia berupa 1 (satu) unit mobil Suzuki Karimun Wagon R.1.0 AB GL MT warna merah metalik telah menimbulkan kerugian bagi PT Indomobil Finance sebab pengalihan objek jaminan fidusia tersebut dilakukan tanpa melalui proses over credit. Hal-hal yang memberatkan dan meringankan atas perbuatan Terdakwa. Hal yang memberatkan adalah perbuatan Terdakwa mengakibatkan kerugian bagi orang lain. Hal yang meringankan adalah Terdakwa mengaku bersalah dan menyesali perbuatannya serta berjanji tidak akan mengulangi lagi perbuatannya, Terdakwa bersikap sopan dan berterus terang serta Terdakwa belum pernah dihukum.

Berdasarkan uraian tersebut, maka dapat diketahui bahwa penjatuhan putusan pemidanaan terhadap pemberi jaminan fidusia yang mengalihkan objek jaminan fidusia tanpa persetujuan tertulis dari penerima fidusia dalam perkara Nomor 43/Pid.B/2018/PN.Kbu adalah didasarkan pada surat dakwaan, alat bukti yang sah, dan segala sesuatu yang terbukti di persidangan serta didukung dengan adanya keyakinan Hakim bahwa Terdakwa terbukti bersalah melakukan perbuatan pidana sebagaimana di dakwakan oleh Penuntut Umum. Disamping itu penjatuhan putusan juga didasarkan pada pertimbangan-pertimbangan yang berkaitan dengan latar belakang Terdakwa melakukan perbuatan pidana, akibat dari perbuatan yang dilakukan oleh Terdakwa, serta hal-hal memberatkan dan meringankan Terdakwa terkait dengan perbuatan yang dilakukannya.

Penjatuhan putusan pemidanaan tersebut menurut penulis selaras dengan teori pemidanaan yang dikemukakan oleh Mackenzie yaitu teori ratio decidendi. Teori ini didasarkan pada landasan filsafat yang mendasar, yang mempertimbangkan segala aspek yang berkaitan dengan pokok perkara yang relevan, kemudian mencari peraturan perundang-undangan yang relevan dengan pokok perkara yang disengketakan sebagai dasar hukum dalam penjatuhan putusan, serta pertimbangan Hakim harus didasarkan pada motivasi yang jelas untuk menegakkan hukum dan memberikan keadilan bagi para pihak yang berperkara. ${ }^{29}$ Mendasar pada teori dasar pertimbangan Hakim dalam menjatuhkan putusan sebagaimana dikemukakan oleh Sudarto dan Mackenzie, maka terkait dengan dasar pertimbangan Hakim dalam menjatuhkan putusan pemidanaan terhadap pemberi fidusia yang mengalihkan objek jaminan fidusia tanpa persetujuan tertulis dari penerima fidusia dapat di analisis bahwa dasar pertimbangan Hakim setidak-tidaknya harus memuat uraian mengenai hal-hal sebagai berikut :

a. Analisis terhadap dakwaan Penuntut Umum atas perbuatan pengalihan objek jaminan fidusia oleh pemberi fidusia tanpa persetujuan penerima fidusia sebagai suatu perbuatan pidana dengan mendasar pada ada atau tidaknya persesuaian antara unsur-unsur Pasal 36 UU Jaminan Fidusia dengan perbuatan yang dilakukan oleh Terdakwa.

b. Analisis terhadap hasil pembuktian berdasarkan alat bukti maupun barang bukti yang diajukan selama persidangan dikaitkan dengan seluruh rangkaian fakta-fakta yang terbukti di persidangan sebagai dasar bagi Hakim untuk menentukan kesalahan Terdakwa atas perbuatan yang dilakukannya.

\footnotetext{
${ }^{29}$ Ahmad Rifai, Penemuan Hukum oleh Hakim dalam Perspektif Hukum Progresif, Sinar Grafika, Jakarta, 2010, hlm hlm 106.
} 
c. Analisis terhadap kemampuan Terdakwa untuk dimintakan pertanggungjawaban pidana dalam hal Hakim berkeyakinan bahwa Terdakwa terbukti secara sah dan meyakinkan bersalah melakukan perbuatan pengalihan objek jaminan fidusia tanpa persetujuan penerima fidusia.

d. Analisis terhadap penentuan pemidanaan yang akan dijatuhkan terhadap Terdakwa dengan mempertimbangkan Pasal 36 UU Jaminan Fidusia maupun ketentuan lain yang terdapat relevansinya dengan perbuatan pengalihan objek jaminan fidusia tanpa persetujuan penerima fidusia.

\section{Kesimpulan}

Jaminan fidusia dikonsepsikan sebagai hak jaminan atas benda bergerak baik yang berwujud maupun yang tidak berwujud dan benda tidak bergerak khususnya bangunan yang tidak dapat dibebani hak tanggungan sebagaimana dimaksud dalam Undang-undang Nomor 4 Tahun 1996 tentang Hak Tanggungan yang tetap berada dalam penguasaan pemberi fidusia, sebagai agunan bagi pelunasan utang tertentu, yang memberikan kedudukan yang diutamakan kepada penerima fidusia terhadap kreditor lainnya. Berkaitan dengan hal tersebut maka diketahui bahwa penguasaan objek jaminan fidusia dilakukan berdasarkan adanya hubungan hukum antara konsumen selaku pemberi jaminan fidusia dengan lembaga pembiayaan selaku penerima jaminan fidusia berdasarkan perjanjian pembiayaan serta akta jaminan fidusia yang telah didaftarkan. Pertanggungjawaban pidana pemberi fidusia yang mengalihkan objek jaminan fidusia tanpa persetujuan tertulis dari penerima fidusia sebagaimana dimaksud dalam putusan perkara Nomor 43/Pid.B/2018/PN.Kbu didasarkan pada adanya kesalahan dari Terdakwa selaku pemberi fidusia yang meliputi kesengajaan atau kelalaian, adapun perbuatan yang dilakukan tersebut merupakan perbuatan yang dilarang dan diancam dengan pidana sebagaimana diatur dalam Pasal 36 UU Jaminan Fidusia. Selanjutnya terhadap kesalahan yang dilakukan dapat dibuktikan bahwa Terdakwa memiliki kemampuan untuk mempertanggungjawabkan perbuatannya dan tidak terdapat alasan pemaaf sebagaimana diatur dalam Pasal 44 Ayat (1) KUHP.

Dasar pertimbangan Hakim dalam menjatuhkan putusan pemidanaan terhadap pemberi fidusia yang mengalihkan objek jaminan fidusia tanpa persetujuan tertulis dari penerima fidusia meliputi:

a. Aspek yuridis, yaitu surat dakwaan Penuntut Umum terhadap Terdakwa dengan melanggar ketentuan Pasal 36 UU Jaminan Fidusia, keterangan saksi dan keterangan Terdakwa, serta barang bukti yang diajukan selama persidangan. Hal-hal tersebut dilakukan suatu analisis oleh Hakim untuk menentukan dan membuktikan kesalahan Terdakwa atas perbuatan mengalihkan objek jaminan fidusia tanpa persetujuan penerima fidusia.

b. Aspek filosofis, yaitu penjatuhan putusan pemidanaan didasarkan pada tujuan untuk melaksanakan penegakan hukum berkaitan dengan adanya perbuatan Terdakwa mengalihkan objek jaminan fidusia tanpa persetujuan penerima fidusia atas dilanggarnya ketentuan Pasal 36 UU Jaminan Fidusia.

c. Aspek sosiologis, yaitu latar belakang perbuatan Terdakwa, akibat perbuatan Terdakwa serta hal yang meringankan dan memberatkan Terdakwa berkaitan dengan pengalihan objek jaminan fidusia tanpa persetujuan penerima fidusia. 


\section{Daftar Pustaka}

A. Buku

Fuady, Munir. 2003. Jaminan Fidusia. Bandung: Citra Aditya Bakti.

Kanter, E.Y \& S.R. Sianturi. 2002. Asas-Asas Hukum Pidana di Indonesia dan Penerapannya. Jakarta: Storia Grafika.

Moeljatno. 1983. Perbuatan Pidana dan Pertanggungjawaban dalam Hukum Pidana. Jakarta: Bina Aksara.

Rifai, Ahmad. 2010. Penemuan Hukum oleh Hakim dalam Perspektif Hukum Progresif. Jakarta: Sinar Grafika.

Rosidah, Nikmah. 2011. Asas-Asas Hukum Pidana. Semarang: Pustaka Magister Semarang.

Sahetapy, J.E. \& Agustinus Pohan. 2007. Hukum Pidana. Bandung: Citra Aditya Bakti.

Syamsuddin, M. 2012. Konstruksi Baru Budaya Hukum Hakim Berbasis Hukum Progresif. Jakarta: Kencana.

Widjaya, Gunawan dan Ahmad Yani. 2005. Jaminan Fidusia. Bandung: Raja Grafindo Persada.

B. Jurnal

Ahyani, Sri. "Perlindungan Hukum Bagi Kreditur Melalui Perjanjian Jaminan Fidusia." Jurnal Wawasan Yuridika. Vol. 24, October 28, 2014: 308-319. https://doi.org/10.25072/JWY.V24I1.19.

Airlangga, Shandi Patria. "Hakikat Penguasa Dalam Negara Hukum Demokratis." Cepalo 3, no. 1, September 17, 2019: 1-10. https://doi.org/10.25041/cepalo.v3no1.1783.

Fanny Kusumaningtyas, "Hukum, Perkembangan, Jaminan Fidusia, Berkaitan Dengan, Hak Cipta, Objek Jaminan, Fidusia Rindia." Nomor 1. Pandecta: Jurnal Penelitian Ilmu Hukum (Research Law Journal) 11, no. 1, August 3, 2016: 96-112. https://doi.org/10.15294/pandecta.v11i1.6465.

Hengky, and Setiawan Kaendo. "Perampasan Oleh Penagih Hutang Terhadap Kendaraan Sebagai Objek Jaminan Fidusia." LEX ET SOCIETATIS. Vol. 7, July 30, 2019: 26-33. https://ejournal.unsrat.ac.id/index.php/lexetsocietatis/article/view/24700.

Heriawanto, "Pelaksanaan Eksekusi Objek Jaminan Fidusia Berdasarkan Title Eksekutorial." Legality: Jurnal Ilmiah Hukum." Accessed July 20, 2020: 54-67, http://ejournal.umm.ac.id/index.php/legality/article/view/8958/6738.

Kurniawan, "Dampak Pelaksanaan Eksekusi Terhadap Obyek Jaminan Fidusia Berdasarkan Pasal 29 Undang Undang Nomor 42 Tahun 1999 Tentang Jaminan Fidusia." Jurnal Pro Hukum: Jurnal Penelitian Bidang Hukum Universitas Gresik. Accessed July 17, 2020: 38-43. http://journal.unigres.ac.id/index.php/JurnalProHukum/article/view/471/347.

Mick, and Mario Valentino Sopacoly. "Akibat Hukum Terhadap Pembebanan Jaminan Fidusia Yang Tidak Didaftarkan." Lex Administratum. Vol. 5, June 14, 2017: 5-16. https://ejournal.unsrat.ac.id/index.php/administratum/article/view/16126.

Octavianus, Aldo. "Hak Debitur Atas Objek Jaminan Fidusia Sebagai Hak Kebendaan Menurut Undang-Undang Nomor 42 Tahun 1999 Tentang Jaminan Fidusia." LEX CRIMEN. Vol. 6, January 31 2018: 19-105. https://ejournal.unsrat.ac.id/index.php/lexcrimen/article/view/18876.

R.Suharto, Faizal Pratama Febriansyah* Purwoto, "Tinjauan Yuridis Kasus Pengalihan Barang Jaminan Fidusia Dari Sudut Hukum Pidana (Studi Kasus Pengadilan Negeri Jepara No.320/Pid.Sus/ 2011/Pn.Jpr Jo No.101/Pid/2012/ Pt.Smg Jo N,” Diponegoro Law Review, vol. 5. No. 2, (2016): 1-16, https://ejournal3.undip.ac.id/index.php/dlr/.

Richard Leonard Jinata, "Tinjauan Yuridis Mengenai Peran Dan Tanggung Jawab Notaris Dalam Pembebanan Jaminan Fidusia,” LEX PRIVATUM, vol. VI, No. 8, February 4, 2018: 120-130, https://ejournal.unsrat.ac.id/index.php/lexprivatum/article/view/22867.

Ridwan, "Efektivitas Penegakan Hukum Tindak Pidana Fidusia Dalam Proses Penyidikan (Studi Di Polres Banyumas)." Jurnal Idea Hukum. Accessed July 20, 2020: 1521-1531. http://jih.fh.unsoed.ac.id/index.php/jih/article/view/1521-1531/104.

Setyawan, David Novan. "Upaya Perlindungan Kepada Pihak Bank Akibat Adanya Pengalihan 
Objek Jaminan Fidusia Yang Dialihkan Oleh Pihak Nasabah Tanpa Adanya Persetujuan Terlebih Dahulu Dari Pihak Bank (Studi Kasus Di PT. Bank Negara Indonesia, Malang)Adapun Upaya Untuk Memberikan.” DIVERSI : Jurnal Hukum 2, no. 1, May 4, 2018: 353-362. https://doi.org/10.32503/diversi.v2i1.144.

Setia Budi, "Permohonan Eksekusi Kepada Pengadilan Negeri Berkaitan Dengan Perjanjian Fidusia Terhadap," JCH (Jurnal Cendekia Hukum), vol. 3, No. 1, September 28, 2017: 99107, http://www.e-jurnal.stih-pm.ac.id/index.php/cendekeahukum/article/view/15.

Sriono, M, and Kn. "Tanggung Jawab Pemberi Fidusia Terhadap Benda Jaminan Fidusia Dalam Perjanjian Kredit." Jurnal Ilmiah "Advokasi 07, no. 02, September 15, 2019: 149-59. https://doi.org/10.30641/dejure.2018.V18.183.

Winarno, Jatmiko. "Perlindungan Hukum Bagi Kreditur Pada Perjanjian Jaminan Fidusia." Jurnal Independent 1, no. 1 (June 1, 2013): 44-55.

http://jurnalhukum.unisla.ac.id/index.php/independent/article/view/5. 
